\title{
An Empirical Study of the Impact of RMB Exchange Rate Fluctuations on Sino-US Trade
}

\author{
Yatong $\mathrm{Ni}^{1}$ \\ ${ }^{1}$ Dongwu Business School, Soochow University, Suzhou, Jiangsu, 215000
}

\begin{abstract}
In recent years, the US has urged the yuan to appreciate in order to resolve its trade deficit with China. This article systematically analyzes the basic situation of the RMB exchange rate changes and the development of Sino-US import and export trade in the past 20 years, and uses Eviews to construct a measurement model to confirm that the impact of the RMB exchange rate on Sino-US trade is not as good as the economic development of the importing country The impact is significant, and the intention of the United States to improve the trade deficit by prompting the appreciation of the renminbi is ineffective. It also puts forward the policy recommendations that attach importance to the impact of excessive US consumption on Sino-US trade volume. The US should liberalize strict controls on China's exports, further optimize the product structure of China's imports and exports, and establish exchange rate risk prevention mechanisms.
\end{abstract}

\section{Introduction}

In recent years, China's foreign trade has developed rapidly, and the foreign trade environment has been continuously improved. However, it has also caused dissatisfaction with Western developed countries led by the United States. Therefore, it is of great practical significance to clarify whether the renminbi is an important cause of the imbalance between China and the United States in foreign trade.

Traditional theory generally believes that when the Marshall-Lerner condition is established, the appreciation of the local currency can greatly increase imports and suppress exports, so as to ease the pressure on a country's excessive international trade balance surplus. Since the exchange rate reform in 2005, although the renminbi has maintained a trend of continuous appreciation, China's foreign trade exports to the United States have maintained a rapid growth trend, and China's import and export trade surplus with the United States has become larger and larger, which is contrary to traditional theory. . This trade surplus situation did not change until November 2008 when China's foreign trade imports and exports began to reverse. But since then, the trade surplus has continued to expand rapidly.

At present, domestic and foreign scholars' discussion and research on the RMB exchange rate and Sino-US trade balance of payments balance mainly focus on the validity test of the Marshall-Lerner condition, and many American economists have also found that The appreciation of the RMB can reduce and improve the US-China trade deficit, that is, the RMB exchange rate meets the Marshall-Lerner condition. However, many experts and scholars have shown that the Marshall-Lerner condition is not established, and its measurement methods and sample selection and other influencing factors are closely related to the different results of its research. The topic of this article will discuss the fluctuations of the RMB exchange rate and the status of Sino-US trade and balance of payments in existing balance of payments theories to verify the impact of the RMB exchange rate on Sino-US trade balance of payments, while mining the RMB The mechanism of the impact of exchange rate fluctuations on Sino-US trade volume in order to better understand the role of RMB exchange rate in Sino-US trade balance.

\section{RMB Exchange Rate Fluctuations and China-US Trade Overview}

\subsection{RMB exchange rate fluctuations}

Before China's reform and opening up in 1978, China's economic policy was a highly concentrated planned economy. All domestic products were reasonably distributed by enterprises according to the national plan. The domestic price level was always stable. International trade was also strictly controlled by the state. The renminbi exchange rate corresponding to this is a fixed exchange rate customized by the official. After the reform and opening up, China has carried out two exchange rate consolidations successively, and has maintained a single currency pegged to the US dollar for nearly ten years from 1996 to 2005 .

In July 2005, China implemented a mechanism based on the RMB market supply and demand and exchange rate as the basis for trade conversion, with reference to the actual exchange rate fluctuations of a basket of major currencies. After the exchange rate reform, the real exchange rate of RMB against the US dollar continued to 
appreciate significantly. However, due to the high surplus in the actual trade and balance of payments between China and the United States, which has been significantly reduced for this reason, the United States was very dissatisfied with the real appreciation of China's renminbi during the exchange rate reform. Aspects of trade conflicts and frictions. At the same time, because the 2008 US subprime mortgage crisis triggered the first large-scale global financial crisis, in order to deal with the disorderly fluctuations of the global financial market and promote economic recovery and growth, the Fed decided to change the monetary tightening policy being implemented The interest rate and quantitative easing policies were reformed in the first four rounds, but China's RMB trade and exports remained stable. Although external demand has been reduced due to the impact of the global financial crisis, the trade surplus is still relatively stable. According to the statistics of the official website of the International Monetary Fund (IMF), the annual statistical data of the exchange rate of RMB against the US dollar from 2000 to 2019 is selected to obtain the annual average line chart of the RMB exchange rate shown in Figure 1.
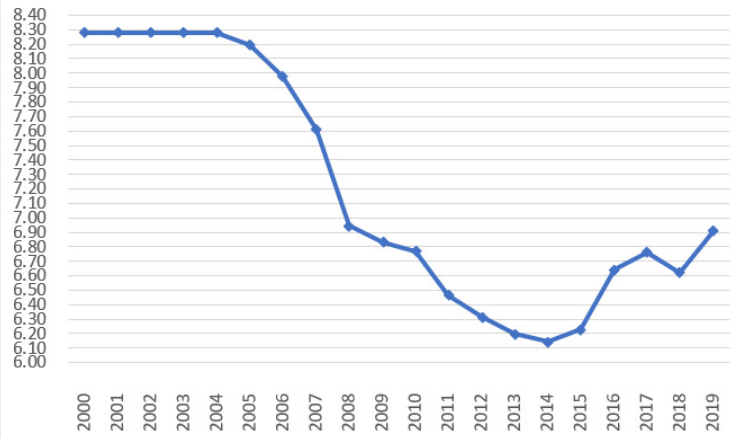

Fig1. The annual average line chart of the exchange rate of RMB to USD from 2000 to 2019 (Unit: RMB/USD)

It can be clearly seen from the data analysis in Figure 1 that since 2000, due to the formulation and implementation of RMB fixed exchange rate and other monetary policies, China's RMB fixed exchange rate has been maintained at 8.28 for a long period of time. The reform of RMB fixed exchange rate in 2005 A more scientific and reasonable mechanism for the formation of market-oriented floating prices of fixed exchange rates of RMB in China has been formed. With marketization of prices and supply-demand relations as the main pricing basis, free market inquiry and trading, market maker independent pricing and trading have been gradually implemented. The system of marketization of floating prices has effectively accelerated the adjustment and reform and opening up of China's RMB fixed exchange rate. After a period of time, the RMB exchange rate was generally in a state of substantial appreciation, reaching 6.14 in 2014. However, since 2016, China's RMB exchange rate has generally depreciated substantially, and the exchange rate has generally shown a two-way fluctuation adjustment. In order to maintain external confidence in the local currency and stabilize exchange rate fluctuations, from early 2016 to 2017 , China adjusted and reformed the exchange rate mechanism, further strengthened the self-regulation of the foreign exchange market, and achieved certain results in the short term.

\subsection{China-US trade analysis}

Generally speaking, since the new century, the economic and trade relations between China and the United States have developed rapidly. China has provided the United States with a broad market environment. China has introduced advanced technology and equipment from the United States and purchased large amounts of agricultural products as reserves. Both China and the United States have benefited from economic exchanges and achieved a win-win situation.

According to Chinese statistics, the total import and export trade volume between China and the United States in 2000 was only 74.462 billion U.S. dollars. It exceeded 100 billion yuan in 2003 to 126.3 billion U.S. dollars, and exceeded 200 billion U.S. dollars in 2005. Since then, due to the severe impact of the economic crisis in 2008, ChinaUS trade and imports and exports have both declined significantly in 2009, but they quickly recovered and surpassed previous levels in 2010. After breaking through the 500 billion mark in 2013, they showed a relatively stable growth trend.

China has always been in a favorable position in terms of the total bilateral trade volume and revenue and expenditure growth rate between China and the United States in the past two decades. Between 2001 and 2004, China's economy developed rapidly, and 2004 was almost higher than that in 2002. Doubled, the average annual trade surplus growth rate at this stage is about $22.86 \%$. Since then, the Sino-US trade balance has gradually entered a stable stage. From 2005 to 2009, China's trade surplus averaged 147.232 billion U.S. dollars, with an average annual growth rate of $6.99 \%$. From 2010 to 2019 , China's trade surplus remained at an average annual rate after breaking through 200 billion U.S. dollars. An increase of $7.96 \%$.

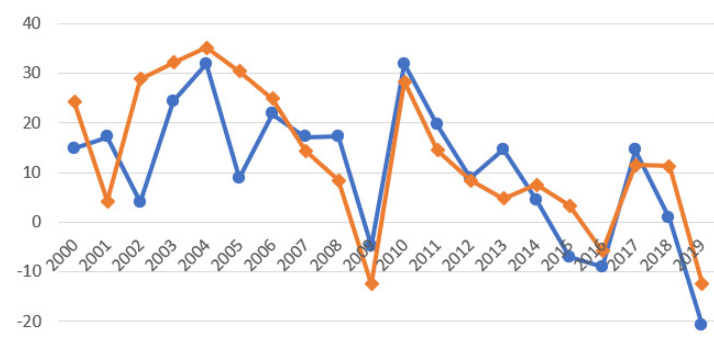

Fig2. The trend of China's import and export growth rate from 2000 to 2019

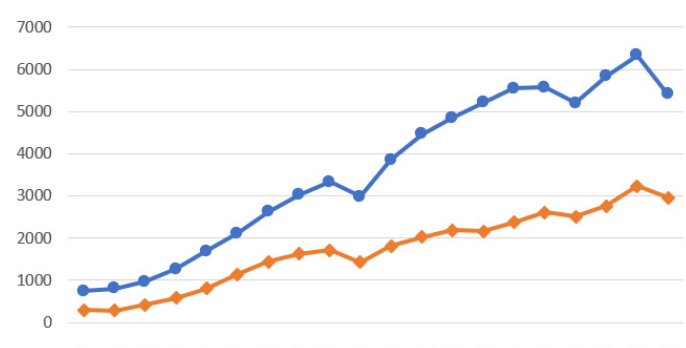

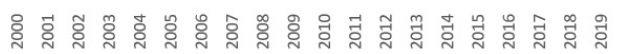

Fig3. 2000-2019 China-US trade volume and its balance change trend curve unit: 100 million US dollars 


\section{An Analysis of the Mechanism of the Impact of RMB Exchange Rate Fluctuations on Sino-US Trade}

Incomplete exchange rate theory mainly studies the transfer coefficient of exchange rate prices. Prior to this, traditional theories such as Marshall-Lerner condition believed that the rise in exchange rate would increase domestic exports by the same proportion, and the relative price of imported goods would also decrease by the same rate, that is, the exchange rate transfer rate was $100 \%$, and This same proportion change will also be fully reflected in the import and export trade of the two countries.

In addition, the exchange rate transfer rate of $100 \%$ means that changes in the price of commodities caused by changes in the exchange rate will be fully borne by the importer. However, this is not the case. Spite and Mofete have analyzed the relevant data of the United States from 1973 to 1979 and 1967 to 1987 and found that the transmission rates of US exports and imports from 1973 to 1979 are $100 \%$ and $30 \%, 1967-1987$ were between $30 \%$ $35 \%$ and $10 \%-20 \%$ respectively. Moreover, there are relevant empirical studies showing that the transfer efficiency of exchange rate changes to import prices will be greatly reduced. Therefore, the premise of the complete exchange rate assumption makes certain theoretical loopholes exist in the elastic analysis method and the $\mathrm{J}$ curve effect.

Therefore, exchange rate fluctuations have an impact on a country's import and export trade, but there will be a time lag effect, and the specific degree of influence will depend on the income level of the importing country, the supply capacity of the exporting country, the type of product, and the decision of the export manufacturer. The factors vary, and it is precisely because of the incomplete transmission of exchange rates that changes in exchange rates do not have much impact on Sino-US trade.

\section{Effect of RMB Exchange Rate Fluctuation on Sino-US Trade Volume}

\subsection{Model building}

According to the theory of international trade, China's exports to the United States are mainly affected by the income level of American consumers and the relative prices of China's exports. The former is a country's consumption elasticity and the latter is price elasticity. This article establishes an export measurement model and introduces exchange rate factors. The model is as follows:

$$
\mathrm{EX}_{\mathrm{t}}=\alpha_{\mathrm{x}}\left(\mathrm{RER}_{\mathrm{t}}\right)^{\beta_{\mathrm{x}}}\left(\mathrm{Y}_{\mathrm{t}}\right)^{\omega_{\mathrm{x}}}
$$

In order to eliminate heteroscedasticity, this model is logarithmized:

$$
\ln \left(E X_{t}\right)=\alpha_{x}+\beta_{x} \ln \left(R_{E R}\right)+\omega_{x} \ln \left(Y_{t}\right)+\varepsilon_{x t}
$$

Among them, EX represents the actual export value of one country to another country at time $t$, REERt represents the real exchange rate at time $t$, and Yt represents the income level of the importing country at time t. The premise of this econometric model is that the price elasticity of China's exports is infinite, that is, only US demand is considered.

The purpose of this article is to fully consider the decisive impact of the appreciation or devaluation of the RMB on Sino-US merchandise import and export trade. The price elasticity of China's merchandise export supply cannot be infinite. Therefore, it is necessary for this article to consider the impact of China's supply capacity, but it is limited For the acquisition of data, this article does not consider the impact for the time being. In addition, the relative price of exported products is also an important factor that directly affects a country's export volume. The relative price of China's exports to the United States is selected as an independent variable. In the end, this article selected the three variables of the real exchange rate of RMB against the US dollar, the real GDP of the United States and the relative export price of Chinese exports as independent variables. The trade volume of China's exports to the United States was the dependent variable. The export measurement model was established as follows:

$$
\ln \mathrm{Y}=\lambda_{0}+\lambda_{1} \ln \mathrm{X}_{1}+\lambda_{2} \ln \mathrm{X}_{2}+\lambda_{3} \ln \mathrm{X}_{3}+\varepsilon
$$

In the model, $\mathrm{Y}$ refers to the trade volume of goods exported from China to the United States; X1 refers to the real exchange rate of RMB against the US dollar, X2 refers to the real US GDP that measures the real income level and import demand of the United States, X3 refers to the relative price of exported products, and $\varepsilon$ is the residual Difference.

Similarly, China's imports from the United States are also affected by the actual income level of Chinese consumers and the relative prices of imported products from the United States. Exchange rates have been added. This article mainly selects the real exchange rate of RMB against the US dollar, China's actual GDP and The three factors of relative prices of imported products are independent variables, and an import measurement model is constructed:

$$
\ln \mathrm{Y}^{*}=\lambda^{*}{ }_{0}+\lambda^{*}{ }_{1} \ln \mathrm{X}_{1}+\lambda^{*}{ }_{2} \ln \mathrm{X}^{*}{ }_{2}+\lambda^{*}{ }_{3} \ln \mathrm{X}_{3}{ }_{3}+\varepsilon^{*}
$$

Among them, $\mathrm{Y}^{*}$ represents the trade volume of goods imported by China from the United States, $X^{*} 2$ refers to China's income level, expressed in terms of China's GDP, $X^{*} 3$ refers to the relative price of China's imports from the United States, and $\varepsilon^{*}$ represents the residual item .

\subsection{Empirical analysis}

The main time-variant series data selected in this article include China's imports from the United States, China's exports to the United States, RMB exchange rate, US GDP, China's GDP, relative prices of export products, and relative prices of imported products. In order to accurately test whether the time series variables are completely stable, we first need to perform stationarity tests on these time series variables in turn. Here we use the ADF test method to test each time series variable. The main results and stability are shown in Table 2 .

The unit root test results of each time series variable are all, and the data after logarithmic processing are all unstable. According to the basic idea of the cointegration theory, although the time variable series itself is not a stationary series, their linear combination may actually be stationary. 
After Eviews10 uses the least square method to process the above data, perform multiple linear regression analysis.

The regression analysis can determine the probability coefficient through the corrected $\mathrm{P}$ statistic value. If $\mathrm{R} 2$ is 0.521971 , it indicates that the model has a better degree of fitting. The horizontal observation coefficient value of the $\mathrm{F}$ statistic value is 42.22095 . If the statistical value gives a significant level observation probability $\alpha$ of 0.05 , then the probability coefficient $\mathrm{p}$ value is less than 0.05 . Rejecting the null hypothesis, China's export trade volume to the United States and the exchange rate of the two countries The linear relationship between US GDP and the relative prices of Chinese and US exports is significant, and the linear model chosen is reasonable.

Regarding the RMB exchange rate, the significance of the regression coefficient and the standard observation value of the test standard t statistic is -4.101511 , and the standard error of the $t$ statistic is 0.364815 , so the real exchange rate has a significant linear impact on the export volume of China and the United States.

In terms of the income level of the United States, the $t$ value is 7.867145 , and the standard error is 0.267582 . It can be seen that the linear impact of the US GDP on the export trade volume between China and the United States is also significant.

However, the statistical value of the regression coefficient $\mathrm{t}$ of the relative prices of export products is 3.171368 , and the standard error is 1.366205 . Therefore, the linear effect of the relative prices of export products on the export trade volume between China and the United States is also significant.

Therefore, the regression equation is:

$\ln Y=-16.46816-1.496294 * \ln X_{1}+2.105105 * \ln X_{2}+4.332737 * \ln X_{3}$

From this, the following conclusions can be drawn: (1) The estimated export elasticity coefficient of China and the United States is -1.496294 , which also means that for every $1 \%$ appreciation of the RMB against the US dollar, the export volume of China and the United States will decrease by $-1.496294 \%$, but due to the value of this coefficient Therefore, the appreciation of the renminbi will have a lesser impact on the reduction of Sino-US exports. (2) The impact of the income level of the United States is positive, and the impact is greater than that of the exchange rate. For every $1 \%$ increase in US GDP, SinoUS exports will rise by $2.105105 \%$. (3) Among the three influencing factors, the influence of US income level is greater than the influence of Sino-US bilateral exchange rates on the export trade of the two countries.

\section{Enlightenment and policy recommendations}

\subsection{The appreciation of the renminbi is difficult to reduce the Sino-US trade surplus}

The substantial appreciation of the RMB exchange rate will not directly reduce the trade surplus between China and the United States. The United States' claim that the high trade surplus that directly affects the trade balance between China and the United States is attributed to the
RMB exchange rate has almost no practical theoretical basis. Therefore, in order to solve the problem of Sino-US trade imbalance, we cannot completely rely on the appreciation of the floating exchange rate of the RMB.

\subsection{Pay attention to the impact of US excessive consumption on the high Sino-US trade surplus}

The results of quantitative analysis show that although the appreciation of the renminbi will greatly reduce China's investment and exports to the United States to a certain extent, its impact on China is far less significant than that of the United States' own income and savings, and the CPI index is too high. Therefore, in solving this problem, the United States should focus more on adjusting its domestic consumption, rather than on the exchange rate of the renminbi.

\subsection{The United States should liberalize strict controls on exports to China}

In recent years, the further increase in the income level of Chinese domestic residents has led to an increase in demand for American products, which is much greater than the possible macroeconomic impact of the appreciation of the renminbi in recent years. Although the growth rate of the U.S. economy in recent years has been far lower than that of China, the increase in US imports of Chinese goods in recent years has been much higher than the increase in China's imports from the United States. Therefore, the United States should further reduce the Sino-US trade surplus by reducing its export controls on China, rather than attributing all the reasons to the RMB exchange rate issue.

\subsection{Further optimize the main product categories and structure of China's import and export products}

Through the above analysis and statistical results, it can be seen that although the RMB exchange rate has a significant impact on Sino-US trade, its influence is very small. One of the reasons why the RMB exchange rate has an insignificant impact on the trade volume of imports and exports between China and the United States is that China's processing The added value of export products directly brought about by traditional trade activities based on product export trade activities and the advantage of excessively relying on the advantage of reducing labor costs is generally at a low level, while the marginal added value of imported products is relatively high.To increase the added value of China's export products, enterprises are upgrading from labor-intensive to technology-intensive.

\section{References}

1. Shen Yufei. Analysis of the relationship between RMB exchange rate and Sino-US trade imbalance from the Sino-US trade war [J]. China Business Review, 2019(17): 97-99. 
2. Guo Xiaoyun. Research on the relationship between RMB exchange rate and Sino-US trade imbalance [D]. Capital University of Economics and Business, 2017.

3. Mundell Robert. China Should Maintain Exchange Rates For Yuan[N], Xinhua News Agency,2009.

4. Peng Xingyun. The motivation and impact of RMB exchange rate reform and level adjustment[J]. Bank of China, 2015(09):63-66. 